\title{
Response of chilli to drip irrigation on sandy clay loam soil under Madukkur soil series (Typic ustropept) in cauvery New Delta Zone
}

\author{
S. Suganya \\ Department of Soil Science and Agricultural Chemistry, TNAU Information and Training Centre, \\ Chennai (T.N.) India
}

\begin{abstract}
In Tamil Nadu, one of the most important agro-climatic zone dictating the total rice production is by Cauvery Delta zone. In Cauvery Delta zone the area under rice cultivation has been reduced drastically and this situation forms the base for a paradigm shift from rice cultivation to alternate crops that requires less amount of irrigation water. Suitable alternate cropping pattern plays an important role in improving the purchasing power of farmer with the help of inclusion of commercial crops in rice based cropping system. Chilli is an important spice cum vegetable crop cultivated extensively in India. This project is indented to study the fertigation system in one of promising alternate crops in chillies in rice ecosystem. By keeping all these points in view, the present investigation was undertaken to study the response of chilli to drip irrigation on sandy clay loam soil under Madukkur soil series (Typic Ustropept) in cauvery new delta zone. Field experiment was conducted at Soil and Water Management Research Institute, Kattuthottam, Thanjavur financially supported by Department of Science and Technology under SERB programme with a budget outlay of Rs. 13.0 lakhs for three years during 2012-2015 in strip plot design with four replications. The results revealed that Sub surface drip fertigation at $10 \mathrm{~cm}$ depth recorded the maximum plant height, number of branches, number of flowers and number of fruits at $\mathrm{B}_{2}$ irrigation regime $(\mathrm{IW} / \mathrm{CPE}=0.75)$. Total green chillies yield was higher under sub surface drip fertigation @ $10 \mathrm{~cm}$ depth at IW/CPE $=1\left(15.59 \mathrm{t} \mathrm{ha}^{-1}\right)$ followed by surface drip fertigation at IW/CPE $=0.75\left(13.50 \mathrm{tha}^{-1}\right)$ and sub surface drip fertigation@10 cm depth at IW/CPE=0.75 $\left(11.17 \mathrm{tha}^{-1}\right)$.Thus, introduction of chillies as an alternate crop under sub surface drip fertigation@10 cm depth technology during January under Broad bed furrow method of cultivation paves the way for improving the social security to the rice farmers.
\end{abstract}

Key Words : Chilli, Sub surface drip fertigation, Madukkur soil series, Cauvery New Delta Zone

View Point Article : Suganya, S. (2021). Response of chilli to drip irrigation on sandy clay loam soil under Madukkur soil series (Typic ustropept) in cauvery New Delta Zone. Internat. J. agric. Sci., 17 (AAEBSSD) : 215-221, DOI:10.15740/HAS/IJAS/17-AAEBSSD/215221.Copyright@2021: Hind Agri-Horticultural Society.

Article History : Received : 27.07.2021; Revised : 30.07.2021; Accepted : 01.08.2021

\section{INTRODUCTION}

In Tamil Nadu Rice is primarily grown under submerged condition in river command areas. One of the most important agro climatic zones dictating the total rice production of the state is by Cauvery Delta zone. In Cauvery Delta zone rice is being cultivated to an extent of 4.5 lakh ha as per the latest statistics available. This 


\section{S. Suganya}

area has been reduced from 6 to 8 lakh ha over a period of 10 to 15 years as a direct consequence of declining water availability in river cauvery in conjunction with water dispute between the states of Tamil Nadu and Karnataka. This situation forms the base for a paradigm shift from rice cultivation to alternate crops that requires less amount of irrigation water. In addition to the yield, Sustainability alternate cropping pattern plays an important role in improving the purchasing power of farmer with the help of inclusion of commercial crops in rice based cropping system. Chilli (Capsicum annuum L.) is an important spice cum vegetable crop cultivated extensively in India. India contributes one fourth of world's population of chilli. In India, chilli is mainly grown in Andhra Pradesh, Karnataka, Tamil Nadu and Orissa. In recent years, apart from export of dry chilli, value added products viz., the chilli powder and also the oleoresin are exported. Even for a garden land crop there is no guarantee that irrigation water in conjunction with rainfall is sufficient enough to innovative method of irrigation which improves productivity of crops with limited availability of water, providing the social security forthe resource poor rice farmers.

Most of the water use in India is for irrigation amounting to 94 per cent of total withdrawal. With increasing population, urbanization and contagious depletion of natural resources, there has to be a paradignm shift in farmers's perception from production to productivity and profitability (Utpal Das et al., 2017). However, by 2025 A.D., when industrial and urban demand increases, the proportion of water use for irrigation reduces to 83 per cent of the total withdrawal. According to National Commission on Agriculture, the utilization of water for purposes other than irrigation is expected to raise to 27 per cent of available fresh water and only 73 per cent of fresh water will be available for irrigation. Therefore, sources of water are to be used efficiently. Limited supply of water necessitates a shift in the production objectives from attainment of potential yield per unit of land to potential yield per unit of water. Among different methods of irrigation, drip method results in maximum water and nutrient use efficiency. In recent years, there is declining trend in annual rainfall. Limited sources of irrigation water from wells and tanks can be advantageously used through drip irrigation to enhance water use efficiency in broadly spaced crops like chilli. The yield and quality are the important factors to be considered which can be achieved only through optimum nutrients application. Chilli being a long duration crop, it responds to split application of nutrients.

This project is indented to study the fertigation system in one of promising alternate crops in chillies in rice ecosystem. Chillies are widely grown as vegetable cum commercial crops which requires $650-750 \mathrm{~mm}$ of water under conventional method of irrigation. Research has shown that drip irrigation has the ability to reduce the water requirement to the tune of $40-50 \%$ without much of yield loss.

It is hypothesized that drip fertigation provides balanced nutrition to crops on daily basis that commensurate with nutrient and moisture demand of the crop. This Fertigation system assists in nourishing the crop sufficiently with moisture and nutrient that facilitates the crop to yield normally with the limited amount of irrigation water. The factors associated with moisture and nutrient dynamics under fertigation and conventional system was extensively studied to gain insight into the mechanism associated with higher water use efficiency and yield of chilli. By keeping all these points in view, the present investigation was undertaken to study the response of chilli to drip irrigation on sandy clay loam soil under Madukkur soil series (Typic Ustropept) in cauvery new delta zone.

\section{Material AND Methods}

The experiment was conducted at Soil and Water Management Research Institute,Kattuthottam, Thanjavur financially supported by Department of Science and Technology under SERB programme with a budget outlay of Rs. 13.0 lakhs for three years during 2012-2015. The treatment details are as follows.
Design
Horizontal strip plot (A) : Drip
A1 : Surface
A2 : Sub surface @ $10 \mathrm{~cm}$ depth
A3 : Sub surface@20 cm
Vertical strip plot $\quad$ (B) : Irrigation regimes depth
Irrigation regimes
IW/CPE $=1$
$\begin{array}{ll}\mathrm{B} 1 & : \mathrm{IW} / \mathrm{CPE}=1 \\ \mathrm{~B} 2 & : \mathrm{IW} / \mathrm{CPE}=0.75\end{array}$
B3 : IW/CPE $=0.5$
Replication :Four
- The recommended dose of fertilizer for chilli is 120:80:80 kg N, $\mathrm{P}_{2} \mathrm{O}_{5}$ and $\mathrm{K}_{2} \mathrm{O}$. Out of which, $75 \%$ of the recommended dose of $\mathrm{P}_{2} \mathrm{O}_{5}$ will be applied basally 
Response of chilli to drip irrigation on sandy clay loam soil under Madukkur soil series (Typic ustropept) in cauvery New Delta Zone

\begin{tabular}{|llll|}
\hline \multicolumn{4}{|l|}{ Table A : Methods employed for the analysis of soil samples } \\
\hline Sr. No. & Properties & Methods & References \\
\hline 1. & $\mathrm{pH}$ & Potentiometry method & Jackson (1973) \\
2. & Electrical Conductivity $\left(\mathrm{d} \mathrm{Sm}^{-1}\right)$ & Conductometry method & Jackson (1973) \\
3. & Organic carbon $(\%)$ & Chromic acid wet digestion & Walkley and Black (1934) \\
4. & Available nitrogen $(\mathrm{kg} / \mathrm{ha})$ & Alkaline permanganate method & Subbaiah and Asija (1956) \\
5. & Available phosphorus $(\mathrm{kg} / \mathrm{ha})$ & $0.5 \mathrm{M}$ sodium bicarbonate (pH 8.5) Olsen's method & Olsen et al. (1954) \\
6. & Available potassium $(\mathrm{kg} / \mathrm{ha})$ & Flame photometer method & Stanford and English (1949) \\
7. & Soil moisture $(\%)$ & Gravimetric method & Jackson (1973) \\
\hline
\end{tabular}

and the remaining will be applied through drip with water soluble fertilizers. The entire $\mathrm{N}$ and $\mathrm{K}_{2} \mathrm{O}$ was applied through drip system with water soluble fertilizers.

- Drip fertigation schedule was given once in three days as per the TNAU Crop Production Guide (TNAU CPG-Horticulture, 2013) recommendation.

Initial soil sample was collected and analysed for their physico-chemical properties. The soil is sandy clay loam in texture. The experimental soil had pH 6.2, EC $0.18 \mathrm{dS} \mathrm{m}^{-1}$, organic carbon $0.30 \%$, available nitrogen, phosphorus and potassium were $160 \mathrm{~kg} \mathrm{ha}^{-1}, 35 \mathrm{~kg} \mathrm{ha}^{-1}$ and $120 \mathrm{~kg} \mathrm{ha}^{-1}$, respectively. The methods employed for the analysis of soil samples are as follows in Table A.

Field experiments were conducted during 2013-15. Nursery was raised with Sierra chilly hybrid at SWMRI and transplanting was done with 35 days old Sierra old seedlings at SWMRI, Thanjavur. Drip irrigation is given based on the potential evaporation as per the technical programme. Fertigation is given as per the fertigation schedule prescribed in CPG-Horticulture 2013. Observations on growth and yield parameters viz., plant height, number of branches per plant, number of flowers per plant and number of fruit per plant were recorded on 45, 90 and 135 days after transplanting(DAT). Total green chillies yield was recorded.

\section{RESUlTS AND DisCuSSION}

The data on plant growth and yield parameters are presented in Table 1 to 5. The results revealed that among the drip systems sub surface drip fertigation @ $10 \mathrm{~cm}$ depth (A2) recorded the maximum plant height 47.5, 94.4 and $97.5 \mathrm{~cm}$ at 45, 90 and 135 DAT. The plant height was maximum in IW/CPE ratio of 1 (B1) followed by $\mathrm{B} 3$ (IW/CPE=0.5). Among the treatment combinations sub surface drip fertigation @ 10 cm depth with IW/ $\mathrm{CPE}=1$ (A2B1) recorded the maximum plant height followed by A3B1 at 45, 90 and 135 DAT (Table 1).

More number of branches was recorded under surface drip fertigation at 45 DAT whereas, sub surface drip fertigation@10 cm depth (A2) recorded the less number of branches at 90 and 135 DAT. Among the irrigation regimes more number of branches was recorded under IW/CPE ratio of 1 (B1) followed by B3 (IW/ $\mathrm{CPE}=0.5$ ) at 45,90 and $135 \mathrm{DAT}$. Among the treatment combinations sub surface drip fertigation@10 cm depth with $\mathrm{IW} / \mathrm{CPE}=1$ (A2B1) recorded the more number of branches followed by A3B1 at 45, 90 and 135 DAT (Table 2).

It has been found that among the drip systems sub surface drip fertigation @ $10 \mathrm{~cm}$ depth (A2) recorded the more number of flowers and fruits at 45, 90 and 135 DAT. More number of flowers were present in IW/CPE

\begin{tabular}{|c|c|c|c|c|c|c|c|c|c|c|c|c|}
\hline & \multicolumn{4}{|c|}{45 DAT } & \multicolumn{4}{|c|}{$90 \mathrm{DAT}$} & \multicolumn{4}{|c|}{$135 \mathrm{DAT}$} \\
\hline & B1 & $\mathrm{B} 2$ & B3 & Mean & B1 & $\mathrm{B} 2$ & B3 & Mean & B1 & B2 & B3 & Mean \\
\hline Al & 47.4 & 46.2 & 44.3 & 46.0 & 92.4 & 82.9 & 88.8 & 88.0 & 95.9 & 86.0 & 92.4 & 91.4 \\
\hline A2 & 49.1 & 46.2 & 47.1 & 47.5 & 97.0 & 94.6 & 91.5 & 94.4 & 100.2 & 96.0 & 96.2 & 97.5 \\
\hline A3 & 48.8 & 40.3 & 46.3 & 45.1 & 94.8 & 88.9 & 91.4 & 91.7 & 99.2 & 90.2 & 96.7 & 95.4 \\
\hline \multirow[t]{2}{*}{ Mean } & 48.4 & 44.2 & 45.9 & & 94.7 & 88.8 & 90.6 & & 98.4 & 90.7 & 95.1 & \\
\hline & A & B & $A$ at $B$ & $\mathrm{~B}$ at $\mathrm{A}$ & A & B & $A$ at $B$ & $\mathrm{~B}$ at $\mathrm{A}$ & A & B & $A$ at $B$ & $\mathrm{~B}$ at $\mathrm{A}$ \\
\hline SEd & 0.02 & 0.03 & 0.05 & 0.05 & 4.53 & 2.70 & 5.93 & 4.68 & 3.59 & 2.81 & 5.35 & 4.86 \\
\hline $\mathrm{CD} \mathrm{P}=0.05)$ & 0.05 & 0.06 & 0.10 & 0.11 & NS & NS & NS & NS & NS & 5.90 & NS & NS \\
\hline
\end{tabular}


ratio of 1 (B2) followed by $\mathrm{B} 3$ (IW/CPE=0.5). Among the treatment combinations sub surface drip fertigation (a) $10 \mathrm{~cm}$ depth with IW/CPE=0.75 (A2B2)recorded more number of flowers followed by A3B1 at 45, 90 and 135 DAT (Table 3). A similar trend was followed in number of fruits (Table 4).

Green chillies were harvested in five times and results revealed that sub surface drip fertigation @ 20 $\mathrm{cm}$ depth at IW/CPE $=1$ recorded the highest yield (3502 $\mathrm{kg} \mathrm{ha}^{-1}$ ) followed by sub surface drip fertigation @ 10 cm depth at IW/CPE=0.75 (3129 $\left.\mathrm{kg} \mathrm{ha}^{-1}\right)$. The lowest yield was recorded under surface drip fertigation @ IW/ $\mathrm{CPE}=0.5$ (480 kg ha-1 in first picking. The same trend was followed in $2^{\text {nd }}, 3^{\text {rd }}, 4^{\text {th }}$ and $5^{\text {th }}$ picking (Table 5a).
Total green chillies yield (Table 5b) was higher under sub surface drip fertigation @ $10 \mathrm{~cm}$ depth at IW/CPE=1 $\left(15559 \mathrm{~kg} \mathrm{ha}^{-1}\right)$ followed by sub surface drip fertigation (a) $10 \mathrm{~cm}$ depth at IW/CPE $=0.75\left(11170 \mathrm{~kg} \mathrm{ha}^{-1}\right)$.

Plant growth and fruit yields were directly related to the amount of water applied. Average fruit weight, number and size of peppers were markedly increased by irrigation (O'Dell, 1983 and Pratt, 1983). Yield differences due to irrigation were attributed to increase number of fruits per plant, fruit size, wall thickness and reduced number of non - marketable fruits. Haynes and Herring (1981) reported that the percentage of flower retention and fruit set were highest with irrigation at 560 $\mathrm{mb}$.

\begin{tabular}{|c|c|c|c|c|c|c|c|c|c|c|c|c|}
\hline & \multicolumn{4}{|c|}{45 DAT } & \multicolumn{4}{|c|}{90 DAT } & \multicolumn{4}{|c|}{$135 \mathrm{DAT}$} \\
\hline & B1 & $\mathrm{B} 2$ & B3 & Mean & B1 & $\mathrm{B} 2$ & B3 & Mean & $\mathrm{B} 1$ & $\mathrm{~B} 2$ & B3 & Mean \\
\hline $\mathrm{A} 1$ & 17.7 & 17.3 & 17.0 & 17.3 & 18.6 & 20.7 & 28.6 & 22.6 & 22.6 & 22.9 & 31.6 & 25.7 \\
\hline $\mathrm{A} 2$ & 18.3 & 16.6 & 14.5 & 16.5 & 27.4 & 27.0 & 29.3 & 27.9 & 29.5 & 29.8 & 34.1 & 31.1 \\
\hline A3 & 18.2 & 12.8 & 16.0 & 15.7 & 23.5 & 22.5 & 22.7 & 22.9 & 27.9 & 24.6 & 25.4 & 26.0 \\
\hline \multirow[t]{2}{*}{ Mean } & 18.1 & 15.6 & 15.8 & & 23.2 & 23.4 & 26.9 & & 26.7 & 25.8 & 30.4 & \\
\hline & A & B & $A$ at $B$ & $\mathrm{~B}$ at $\mathrm{A}$ & A & B & $A$ at $B$ & $\mathrm{~B}$ at $\mathrm{A}$ & A & B & $A$ at $B$ & $\mathrm{~B}$ at $\mathrm{A}$ \\
\hline SEd & 1.20 & 2.05 & 3.13 & 3.54 & 1.15 & 1.09 & 4.50 & 3.98 & 1.85 & 2.01 & 3.39 & 3.48 \\
\hline $\mathrm{CD}(\mathrm{P}=0.05)$ & NS & NS & NS & NS & 2.48 & 2.30 & NS & NS & 4.52 & 4.22 & NS & NS \\
\hline
\end{tabular}

\begin{tabular}{|c|c|c|c|c|c|c|c|c|c|c|c|c|}
\hline & \multicolumn{4}{|c|}{45 DAT } & \multicolumn{4}{|c|}{90 DAT } & \multicolumn{4}{|c|}{$135 \mathrm{DAT}$} \\
\hline & $\mathrm{B} 1$ & $\mathrm{~B} 2$ & B3 & Mean & B1 & $\mathrm{B} 2$ & B3 & Mean & B1 & B2 & B3 & Mean \\
\hline A1 & 18.5 & 20.9 & 18.6 & 19.3 & 32.8 & 34.0 & 36.9 & 34.6 & 33.3 & 39.7 & 32.9 & 35.3 \\
\hline A2 & 16.0 & 22.2 & 26.7 & 21.6 & 35.9 & 36.4 & 36.1 & 36.1 & 36.9 & 34.2 & 38.0 & 36.4 \\
\hline A3 & 15.4 & 17.9 & 23.3 & 18.9 & 31.9 & 35.3 & 34.3 & 33.8 & 34.4 & 35.5 & 35.8 & 35.2 \\
\hline \multirow[t]{2}{*}{ Mean } & 16.6 & 20.3 & 22.9 & & 33.5 & 35.2 & 35.8 & & 34.9 & 36.5 & 35.6 & \\
\hline & A & B & $A$ at $B$ & $\mathrm{~B}$ at $\mathrm{A}$ & A & B & $A$ at $B$ & $\mathrm{~B}$ at $\mathrm{A}$ & A & B & $A$ at $B$ & $\mathrm{~B}$ at $\mathrm{A}$ \\
\hline SEd & 1.57 & 2.28 & 3.58 & 3.94 & 4.53 & 1.98 & 5.93 & 4.68 & 1.70 & 2.27 & 3.64 & 3.94 \\
\hline $\mathrm{CD}(\mathrm{P}=0.05)$ & NS & 4.78 & NS & NS & NS & 3.98 & NS & NS & NS & 4.75 & NS & NS \\
\hline
\end{tabular}

\begin{tabular}{|c|c|c|c|c|c|c|c|c|c|c|c|c|}
\hline & \multicolumn{4}{|c|}{$45 \mathrm{DAT}$} & \multicolumn{4}{|c|}{$90 \mathrm{DAT}$} & \multicolumn{4}{|c|}{$135 \mathrm{DAT}$} \\
\hline & B1 & B2 & B3 & Mean & B1 & B2 & B3 & Mean & B1 & B2 & B3 & Mean \\
\hline $\mathrm{A} 1$ & 17.6 & 17.5 & 17.4 & 17.5 & 38.6 & 42.5 & 45.1 & 42.1 & 42.1 & 42.4 & 40.3 & 41.6 \\
\hline $\mathrm{A} 2$ & 20.0 & 19.5 & 20.9 & 20.1 & 45.2 & 43.1 & 43.2 & 43.8 & 42.0 & 39.9 & 46.9 & 42.9 \\
\hline $\mathrm{A} 3$ & 18.5 & 14.7 & 19.3 & 17.5 & 40.1 & 49.9 & 44.1 & 44.7 & 38.9 & 48.6 & 43.1 & 43.5 \\
\hline \multirow[t]{2}{*}{ Mean } & 18.7 & 17.2 & 19.2 & & 41.3 & 45.2 & 44.1 & & 41.0 & 43.6 & 43.4 & \\
\hline & A & B & $A$ at $B$ & B at A & A & B & $A$ at $B$ & B at A & A & B & $A$ at $B$ & $\mathrm{~B}$ at $\mathrm{A}$ \\
\hline SEd & 1.25 & 1.13 & 4.08 & 2.14 & 1.20 & 2.01 & 3.13 & 3.54 & 0.98 & 1.10 & 5.84 & 4.20 \\
\hline $\mathrm{CD}(\mathrm{P}=0.05)$ & 2.84 & 2.05 & NS & NS & 2.46 & 4.05 & NS & NS & 2.01 & 2.20 & NS & NS \\
\hline
\end{tabular}


Response of chilli to drip irrigation on sandy clay loam soil under Madukkur soil series (Typic ustropept) in cauvery New Delta Zone

In chilli plant, produce was greatest at the highest irrigation level (Hassan et al., 1984). Photosynthetic rate decreased to below $50 \%$ of maximum when available soil water capacity was less than 50 per cent (Zira, 1984). Tedeschi and Zerbi (1984) showed that total and marketable yields per plant were linearly related to actual evapo-transpiration and that yield dependent on number of fruits per plant and mean fruit weight rather than on the number of flowers which was less important because abscission of flowers and young fruits was always high.

Klickvenga and Siddiq (1985) opined that chilli was sensitive to both water deficit and surplus, providing too much water results in anaerobic condition within root zone. While insufficient water inhibits leaf expansion and photosynthetic capacity. Pulekar et al. (1993) reported that different levels of irrigation had the significant effect on cost benefit ratio of banana. The highest benefit cost ratio (2.28:1) was recorded with irrigation at $25 \mathrm{~mm} \mathrm{CPE}$ from November to May.

Hedge (1989) reported that irrigation at different soil moisture regimes had significant influence on dry matter production in bell pepper during all the three years of study. Pulekar et al. (1990) reported that irrigation scheduled at $36 \mathrm{~mm}$ CPE increased the chilli yield significantly over 12 and $60 \mathrm{~mm} \mathrm{CPE}$. Investigations carried out at Madurai indicated that irrigation at 0.75

\begin{tabular}{|c|c|c|c|c|c|c|c|c|c|c|c|c|}
\hline \multicolumn{13}{|c|}{ Table 5a : Green chillies yield $\left(\mathrm{kg} \mathrm{ha}^{-1}\right)$ as influenced by different treatments under drip fertigation } \\
\hline & \multicolumn{4}{|c|}{ I Harvest } & \multicolumn{4}{|c|}{ II Harvest } & \multicolumn{4}{|c|}{ III Harvest } \\
\hline & B1 & B2 & B3 & Mean & B1 & B2 & B3 & Mean & B1 & $\mathrm{B} 2$ & B3 & Mean \\
\hline A1 & 2151 & 3129 & 1031 & 2104 & 2409 & 3333 & 1316 & 2353 & 2756 & 3716 & 1769 & 2747 \\
\hline $\mathrm{A} 2$ & 3502 & 2258 & 1573 & 2444 & 3813 & 2622 & 1956 & 2797 & 4320 & 3022 & 2356 & 3233 \\
\hline $\mathrm{A} 3$ & 1547 & 1324 & 480 & 1117 & 1902 & 1644 & 782 & 1443 & 2240 & 2080 & 1227 & 1849 \\
\hline \multirow[t]{2}{*}{ Mean } & 2400 & 2237 & 1028 & & 2708 & 2533 & 1351 & & 3105 & 2939 & 1784 & \\
\hline & A & B & $A$ at $B$ & $\mathrm{~B}$ at $\mathrm{A}$ & A & B & $A$ at $B$ & B at A & A & B & $A$ at $B$ & $\mathrm{~B}$ at $\mathrm{A}$ \\
\hline SEd & 105 & 78 & 153 & 136 & 106 & 76 & 151 & 132 & 108 & 77 & 152 & 132 \\
\hline \multirow[t]{3}{*}{$\underline{\mathrm{CD}}(\mathrm{P}=0.05)$} & 259 & 164 & 347 & 285 & 258 & 159 & 342 & 277 & 263 & 161 & 347 & 278 \\
\hline & & \multicolumn{5}{|c|}{ IV Harv est } & \multicolumn{6}{|c|}{ V Harvest } \\
\hline & & $\mathrm{B} 1$ & B2 & & B3 & Mean & & $\mathrm{B} 1$ & $\mathrm{~B} 2$ & B3 & & Mean \\
\hline A 1 & & 1953 & 2589 & & 1098 & 1880 & & 534 & 734 & 455 & & 574 \\
\hline A2 & & 3213 & 2752 & & 1876 & 2614 & & 711 & 516 & 818 & & 682 \\
\hline A3 & & 1345 & 1095 & & 762 & 1067 & & 578 & 373 & 613 & & 521 \\
\hline Mean & & 2170 & 2145 & & 1245 & & & 608 & 541 & 629 & & \\
\hline & & A & B & & $A$ at $B$ & $\mathrm{~B}$ at $\mathrm{A}$ & & $\mathrm{A}$ & $\mathrm{B}$ & $A$ at $B$ & & $\mathrm{~B}$ at $\mathrm{A}$ \\
\hline SEd & & 118 & 54 & & 141 & 93 & & 123 & 128 & 219 & & 222 \\
\hline $\mathrm{CD}(\mathrm{P}=0.05)$ & & 289 & 112 & & 329 & 195 & & 300 & 269 & 484 & & 466 \\
\hline
\end{tabular}

\begin{tabular}{|c|c|c|c|c|c|c|}
\hline \multirow{2}{*}{$\bar{A}$} & & \multirow{2}{*}{$\begin{array}{c}\text { B1 } \\
9803\end{array}$} & \multirow{2}{*}{$\frac{\mathrm{B} 2}{13501}$} & \multicolumn{2}{|r|}{ B3 } & \multirow{2}{*}{$\begin{array}{l}\text { Mean } \\
9658\end{array}$} \\
\hline & & & & & 5669 & \\
\hline $\mathrm{A}^{2}$ & & 15559 & 11170 & & 8579 & 11769 \\
\hline$A^{3}$ & & 7612 & 6516 & & 3864 & 5997 \\
\hline \multirow{2}{*}{\multicolumn{2}{|c|}{ Mean }} & 10991 & 10396 & & 6037 & \\
\hline & & A & B & & $A$ at $B$ & $\mathrm{~B}$ at $\mathrm{A}$ \\
\hline \multicolumn{2}{|c|}{ SEd } & 138 & 68 & & 154 & 124 \\
\hline \multicolumn{2}{|c|}{$\mathrm{CD}(\mathrm{P}=0.05)$} & 289 & 112 & & 331 & 253 \\
\hline A1 & & & & B1 & $: \mathrm{IW} / \mathrm{CPE}=1$ & \\
\hline $\mathrm{A} 2$ & & & & B2 & $: \mathrm{IW} / \mathrm{CPE}=0.75$ & \\
\hline $\mathrm{A} 3$ & & & & B3 & $: \mathrm{IW} / \mathrm{CPE}=0.5$ & \\
\hline
\end{tabular}




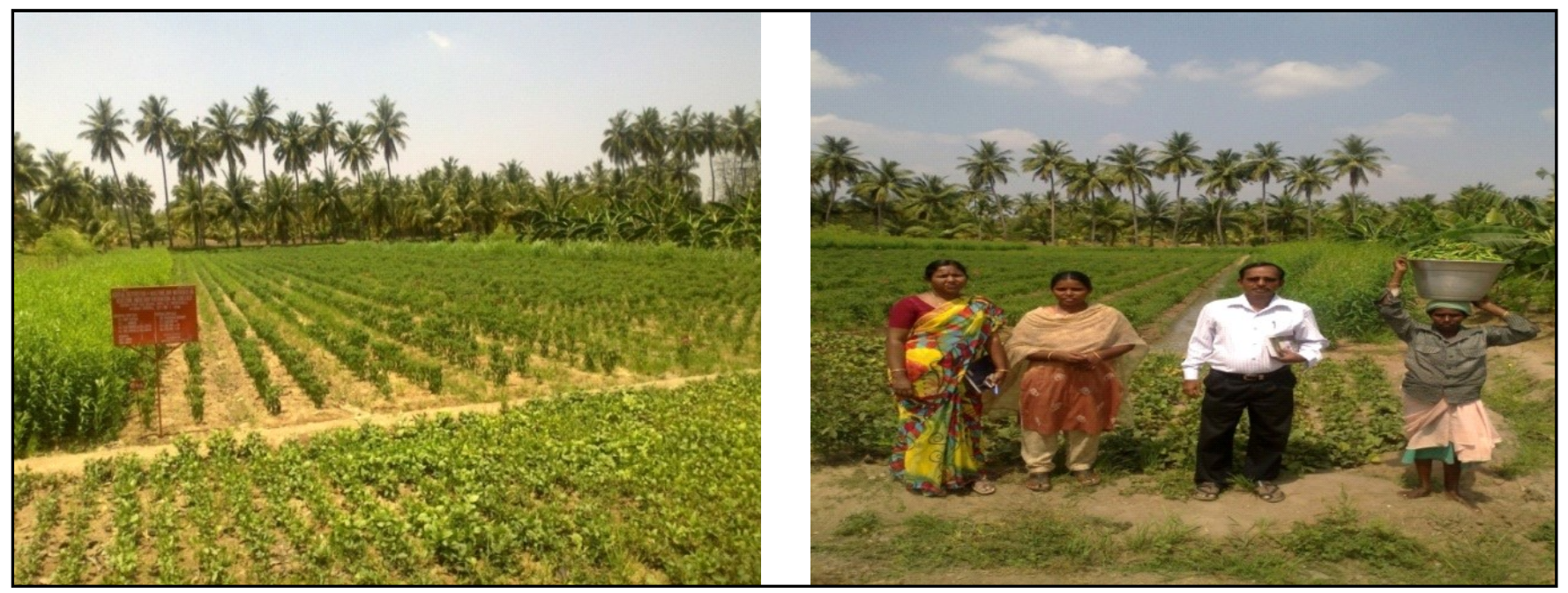

Plate 1 : Overall view of the field experiment

IW/CPE ratio resulted in maximum growth and yield attributes (Shibhila Mary and Balakrishnan, 1990). Similar trend of yield increase was noticed by Doyle et al. (1994).

Scheduling of irrigation at IW/CPE ratio at frequent intervals resulted in significantly higher yields (Gulati et al., 1995; Café Filho and Duniway, 1995). Further, irrigation scheduled at $0.9 \mathrm{IW} / \mathrm{CPE}$ ratio registered 37 , 30 and 10 per cent increased dry chilli yield over 0.45 , 0.60 and $0.75 \mathrm{IW} / \mathrm{CPE}$ ratios, respectively (Subramanian et al., 1998).

Drip irrigation providing only $250 \mathrm{~m} 3$ to $1000 \mathrm{~m} 2$ resulted in a high yield $(400 \mathrm{~kg} / 1000 \mathrm{~m} 2)$ of capsicum (Palevitch et al., 1979). Sivanappan (1979) indicated that irrigation requirements depend on season, weather factors, soil type, type of irrigation and worked out the irrigation requirement of chilli crop to be $100 \mathrm{~cm}$ and $402 \mathrm{~cm}$ in Tamil Nadu under furrow and drip irrigation, respectively.

Ramesh (1986) had conducted an experiment during rabi 1985 at Main Research Station, Hebbal, Bangalore to study the drip and furrow methods of irrigation at different levels ( 0.3 and 0.6 Epan) in green chilli. Higher levels of irrigation recorded more or less same plant height, number of primary branches per plant compared to lower level of irrigation. Higher level of irrigation (0.6 Epan) recorded significantly higher yield of green chilli over lower levels of irrigation.

\section{Summary and Conclusion:}

- Sub surface drip fertigation at $10 \mathrm{~cm}$ depth recorded the maximum plant height, number of branches, number of flowers and number of fruits at $B_{2}$ irrigation regime $(\mathrm{IW} / \mathrm{CPE}=0.75)$.

- Total green chillies yield was higher under sub surface drip fertigation @ $10 \mathrm{~cm}$ depth at IW/CPE=1 $\left(15.59 \mathrm{t} \mathrm{ha}^{-1}\right)$ followed by surface drip fertigation at IW/ $\mathrm{CPE}=0.75\left(13.50 \mathrm{tha}^{-1}\right)$ and sub surface drip fertigation (a) $10 \mathrm{~cm}$ depth at IW/CPE $=0.75\left(11.17 \mathrm{t} \mathrm{ha}^{-1}\right)$.

Thus, introduction of chillies as an alternate crop under sub surface drip fertigation @ $10 \mathrm{~cm}$ depth technology during January under Broad bed furrow method of cultivation paves the way for improving the social security to the rice farmers.

\section{Acknowledgement :}

The author gratefully acknowledges the financial support received from the Department of Science and Technology, Government of India under Science and Engineering Research Board (DST-SERB) scheme. Technical support and encouragement extended by Dr. T. Senguttuvan and Dr. Ravi for the execution of this project at Soil and Water Management Research Institute is also acknowledged.

\section{REFERENCES}

Café Filho, A. C. and Duniway,J. M. (1995). Effects of furrow irrigation schedules and host genotypes on phytophthora root rot of pepper. Plant Disease, 79(1): 39-43.

Doyle, A., Smittle, W., Lamar Dickens and James, R. (1994). Irrigation regimes affect yield and water use by bell pepper. Journal of American Society of Horticultural Sciences, 119(5): 936-939. 
Response of chilli to drip irrigation on sandy clay loam soil under Madukkur soil series (Typic ustropept) in cauvery New Delta Zone

Gulati, J. M. L., Mishra, M. M., Paul, J. C. and Sahu, G. S. (1995). Production potential of chilli under levels of irrigation and nitrogen. Indian Journal of Agronomy, 40(1): 145-146.

Hassan, A.H., Agina, E.A., Saleh, M. M. and El-Wahba, H. (1984). Effect of water regime on the growth and chemical composition of Capsicum annum. Horticulture Abstract, 55(6): 457.

Haynes, R. and Herring, S., (1981). Performance of drip irrigated bell peppers. Irrigation and Drainage Abstracts, 8(2): 970 .

Hedge, D. M. (1989). Effect of method and volume of irrigation on yield and water use of sweet pepper. Indian Journal of Horticulture, 46(2): 225-229.

Jackson, M.L. (1973). Soil chemical analysis. Oxford IBH Publishing Co., Mumbai.

Klickvenga, M. and Siddiq, H. (1985). Soil water and water use of trickle irrigated chilli pepper. Irrigation and Drainage Abstracts, 11: 1437.

O'Dell, C. (1983). Trickle did the trick. American Vegetable Grower, 31(4): 56.

Olsen, S.R., Cole, C.V., Watanabe, F.S. and Dean, L. (1954). Estimation of available phosphorus in soils by exractions with sodium bicarbonate. U.S.D.A. Circular No.939, U.S. Govt. Printing Office, Washington, D.C.

Palevitch, D., Geran, G., Menagem, E., Kalmar, D. and Galili, J. (1979). A preliminary study in growing paprika by drip irrigation. Horticultural Abstracts, 49(12): 806.

Pratt, A. J. (1983). Ane Peppers a problem. American Vegetable Grower, 31(4): 22-24.

Pulekar, C. S., Salvi, B. R., Jadhav, S. M. and Patil, B. P. (1993). Water use and Productivity of Banana as influenced by Irrigation schedule and grass mulch in Lateritic soil of Konkan. J. Water Mgmt. 1: 39-42.
Ramesh, S. (1986). A study on drip and furrow methods of irrigation in green chilli (Capsicum annum L.) under different planting patterns and plant densities. M. Sc. (Ag.) Thesis, University of Agricultural Sciences, Bangalore.

Shibhila Mary, S. and Balakrishnan, R. (1990). Studies on the effect of irrigation, nitrogen and potassium on growth and yield of chilli. Indian Journal of Horticulture, 47(1): 413-416.

Sivanappan, R. K. (1979). Drip irrigation in vegetable crops. Punjab Horticultural Sciences, 19(1/2): 83-85.

Stanford, P. and English, W.L. (1949). Use of the flame photometer in rapid soil tests of potassium and calcium. $J$. Environ. Qual.,21: 635-642.

Subbiah, B.V. and Asija, G.L. (1956). A rapid procedure for the estimation of available nitrogen in soils. Curr. Sci.,25: $259-260$.

Subramanian, P., Krishnaswamy, S. and Mark Devasagyam (1998). Influence of irrigation methods and regimes on the growth and yield of chilli. South Indian Horticulture, 46(1\&2): 99-101.

Tedeschi, P. and Zerbi, G. (1984). Flowering and fruiting courses and yield of sweet pepper plants grown in lysimeter with relation to different water regime. Horticultural Abstracts, 55: 275.

Utpal Das, Bhattacharyya, R. K. and Pathak, Purnima (2017). A Review of works done regarding Precision farming in Banana. Bull. Env. Pharmacol. Life Sci., 6 (Special Issue 2): 354-360.

Walkley, A. and Black. C.A. (1934). An examination of the different method for determining soil organic matter and a proposed modification of the chromic acid titration method. Soil Sci., 37: 29-38.

Zira, L. (1984). On physiological process of sugarbeet and red pepper under controlled conditions of increasing water efficiency. Horticultural Abstracts, 54: 351-353. 